\title{
Labour markets and pension systems
}

\section{Andras Uthoff}

Special Studies

Unit, ECLAC

authoff@eclac.cl
Latin America is going through a simultaneous process of

population ageing and growing predominance of precarious

employment conditions which poses a challenge for contributory pension systems. The solvency of the basic pillars of the unfunded system is being affected by the longstanding decline in the number of active persons whose contributions finance the benefits of retirees. The benefits of the individually funded systems are sensitive to the density of contributions needed to accumulate capital and finance pensions for members with increasingly long life expectancies. This study describes how this challenge manifests itself at present and examines the responsibilities that society must assume in order to cope with it. 
I

\section{Introduction}

Pension systems design mechanisms whose purpose is to finance workers' living expenses during their old age or in the event of disability and to ensure the living expenses of their dependents in the event of their death. Such systems address the economic problem of setting aside part of production for such eventualities (Barr, 2000); thus, they need to identify the sources of financing with which to defray the cost of these benefits. These sources may be the savings of workers and employers, taxes for the public financing of benefits, and insurance premiums for defraying costs in cases of disability and death. If the systems do not include these financing and insurance schemes, it is highly likely that many persons will be left without any form of protection.

This study explains why the current reforms which are based on individual savings schemes and private insurance arrangements (Mesa-Lago, 1999) reproduce the inequality in society and tend to detract from the purpose of the social security system of which the pension schemes are part. Thus, when they obtain their finance on the basis of their members' labour contracts, retirement savings schemes reproduce the problems typical of labour markets in the region. Since a significant proportion of the working age population is unemployed, underemployed or inactive, a system based on such schemes for obtaining the funds needed to provide for the main income earner's living expenses during old age or disability or for those of his survivors after his death would leave many persons underinsured or not insured at all.

\section{II}

\section{The context}

The labour market limits the population coverage of pension schemes in Latin America. In this respect, three aspects of this context which contribute to this situation may be distinguished.

This study was prepared for the Workshop on the Economy and Population Ageing (Mexico City, 16-17 May 2002), organized by the Inter-American Centre for Social Security Studies (CIESS), El Colegio de la Frontera Norte (COLEF) and the National Autonomous University of Mexico (UNAM). The author wishes to
How pension systems in Latin America evolve will depend on the political will shown and on the institutional actions taken to solve this dilemma. Their evolution will depend on the degree of solidarity within the system and on the type of cross subsidies built into it in order to transfer resources from those who have greater capacity to save to those who have less. Society needs to define the redistributive role of the system and to consider how it will be implemented: whether redistribution will be done within the system (through solidary contributions) or from outside of it (through general taxes), but always avoiding the moral hazard that those who can save may take advantage of subsidies.

In order to highlight the importance of this link with the inequalities associated with labour markets, this essay will examine the following aspects: the demographic, economic and labour context in which the systems operate (section II); the functions that the systems should fulfill in these contexts (section III); the basic options for designing the fundamental pillars of these systems (section (IV); the most extreme types of pillars that can be constructed (section V); heterogeneity in terms of access to the benefits provided by pillars based on individual saving (section VI); the liabilities associated with the different options (section VII); the results currently being observed in systems with pillars based on individual saving (section VIII); and finally, the conclusions reached (section IX).

Firstly, the rapid pace of population ageing has positive and negative elements. On the positive side, the working age population that is participating in the economy (the potentially active population that has the

express his gratitude for the comments of Dra. Patricia Olave during the workshop and those of Oscar Altimir on a first draft, as well as the valuable support provided by Nora Ruedi in the preparation of the present version, but he himself bears sole responsibility for the contents of this work. 
capacity to save) is continuing to grow. Another positive fact is that the total number of persons dependent on this population (children of school age, adults who are unemployed and inactive elderly persons) is going down. However, the retirement-age population is growing steadily (see right-hand column in figure 1). This quantitative indicator of population ageing is rising sharply and will start to gather still more momentum as from 2020.

Secondly, the economies are operating with savings and investment levels of around $20 \%$ of GDP, which are very low for the needs of the region. According to ECLAC studies, such levels are too low to sustain the pace of growth required in order to provide full employment for all economically active persons (ECLAC, 1996). Furthermore, it is observed that when economies are able to attract financing from abroad in the form of external savings (increase in financing with external capital), this does not complement national savings, but reduces domestic saving. Thus, the two sources of financing tend to take each other's place (Titelman and Uthoff, 1997, and figure 2).

Thirdly, as pointed out in ECLAC studies, economic growth has been dependent mainly on external financing, the sources of which have been highly volatile. This, together with the procyclical character of macroeconomic policies in the region, has been reflected in unusually frequent financial crises and in low and unstable economic growth with significant costs in terms of unemployment and poverty (Ocampo, coord., 2001). As already indicated by the International Labour Organisation (ILO) and ECLAC, those who have jobs are subject to increasingly precarious conditions which are reflected in higher rates of unemployment, informality and lack of social protection.

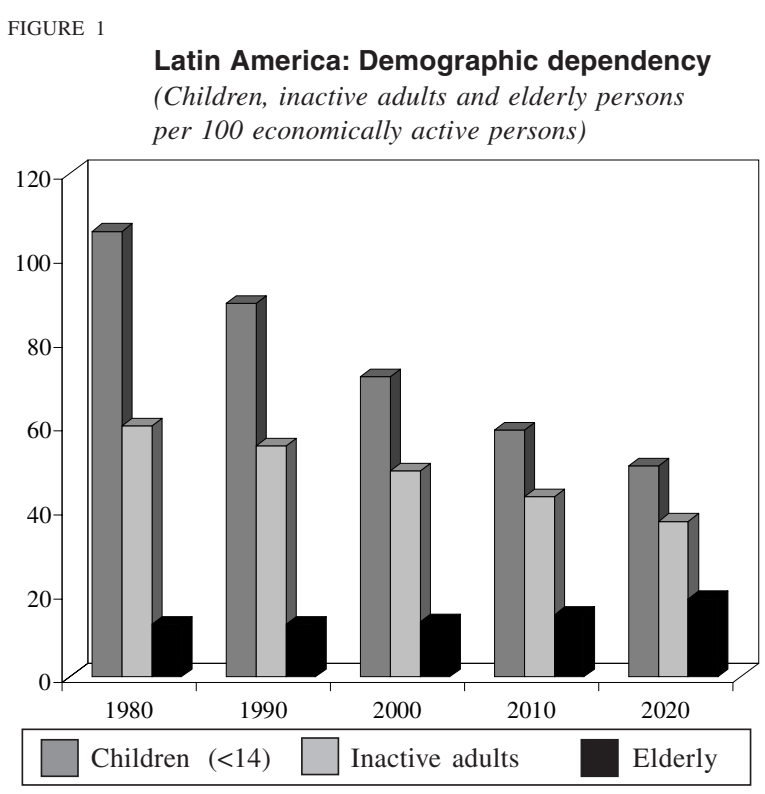

Source: ECLAC/CELADE, 1999 and 2002.

Unemployment rates (which show the numbers of unemployed among the economically active population) are rising (figure 3) and furthermore, the year 2002 was not very promising in this regard, since unemployment rates were of the order of $9 \%$.

Increasing numbers of those who have jobs now work in the informal sector. This is because of the downturn in formal public employment and because job creation in large enterprises grows more slowly than the total labour force looking for work. In Latin America, therefore, most of the employed are tending to be in the informal sector, obviously without social security coverage.

Latin America and the Caribbean: Gross national saving, external saving and real investment (As a percentage of GDP, on the basis of current dollars (for gross national saving

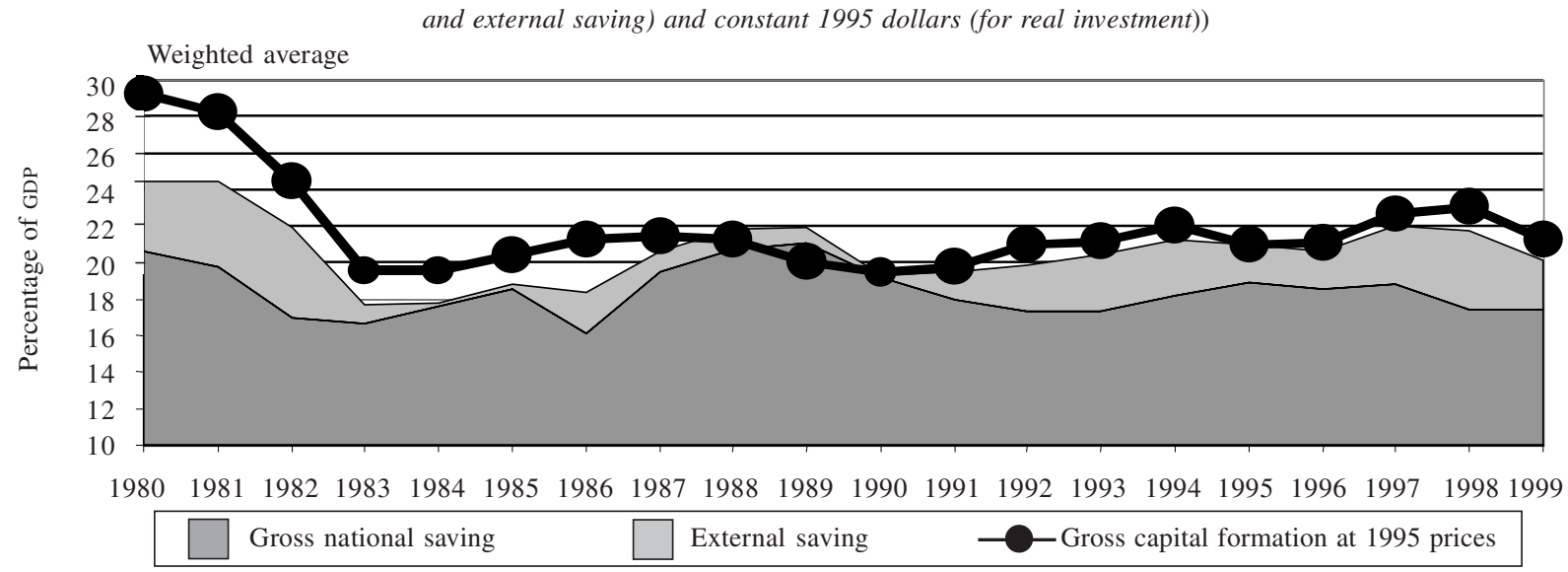

Source: World Bank (2001). 
FIGURE 3

Latin America: Urban open unemployment rate

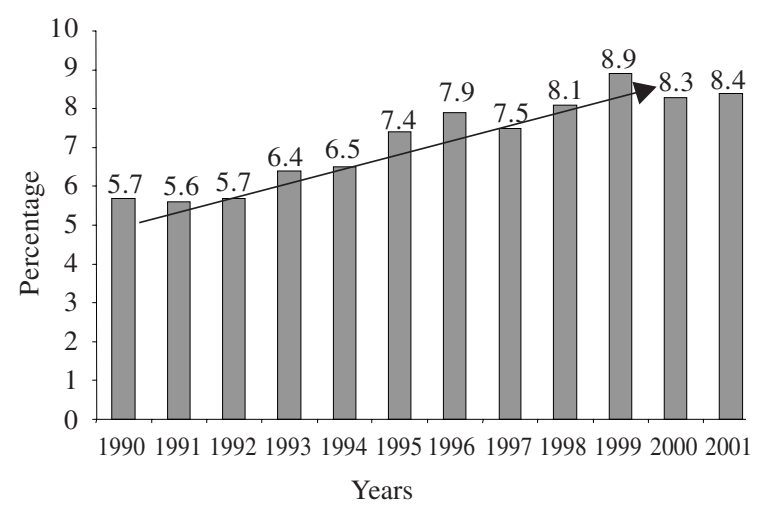

Source: ILO, 2001b.
FIGURE 4

Latin America: Structure of non-agricultural employment

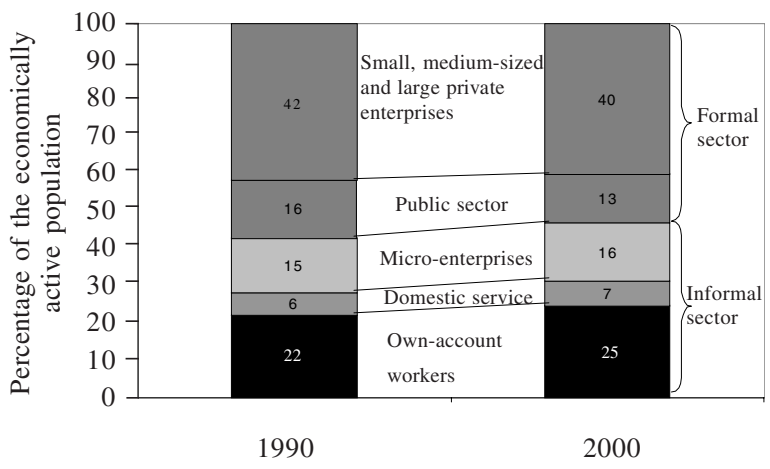

Source: ILO, 2001b.

\section{III}

\section{The functions of pension systems}

Within this context, what the reforms are trying to do is to develop a system that fulfils two types of functions: economic and social. The fundamental social function is to ensure the savings (production) necessary for financing satisfactory levels of consumption during old age, disability and survival. Another important function is that of contributing to equity through solidarity with those who are not in a position to save for their old age. Persons who are unable to save on account of their particular employment status will also grow old one day, and the systems which are designed must decide how to provide for these people. Will they have access to a pension? And if so, under what conditions and how will it be financed?

Such functions obviously cannot be promoted, however, through measures that involve restrictions and a deterioration in economic objectives such as publicsector solvency or the cost of hiring labour. This would occur if, for example, in order to improve coverage, there was a significant increase in contributions and/or the tax burden or fiscal deficit. If we build solidarity into the system, we must identify the source of the solidary funding so that it remains consistent with the objectives of competitiveness and economic solvency.
These economic functions are important and act as conditioning factors for the fulfillment of the social functions pursued.

Contributions to financial savings and to the development of capital markets are sometimes included among the economic functions, and indeed these objectives have been cited a great deal in connection with the individual capitalization model. Highlighting them, however, tends to confuse a means, such as saving, with an end, namely, social protection. Thus, desirable though such objectives may be in themselves, they must be secondary to the design of the system, although they do not by the same token cease to be important. As we will see below, it is not clear either that individual capitalization systems are fulfilling the function of increasing real investment. There is financial saving, but this does not necessarily constitute real investment. Furthermore, in cases where such systems take the place of an unfunded system, the cost of transition has to be financed. ${ }^{1}$

\footnotetext{
${ }^{1}$ See Orszag and Stiglitz (1999) and Barr (2000) for a study of the myths that exist in connection with these issues.
} 


\section{IV}

\section{Options for designing a pension system}

In order to ensure that families set aside a portion of their income as savings for old age, pension systems need to have some idea of their consumption patterns in relation to their current disposable income and its future variations. Since the decision that has to be taken will depend on the income expectations throughout the life of the main income earner, it is said to be intertemporal in character.

The life-cycle theory assumes that a person has an income profile (represented by the gray line in figure 5), which begins when the person enters the labour force, grows up to a certain point and then wanes until it disappears altogether when the person retires or stops working. However, it also assumes that there are conditions for maintaining a relatively stable and, it is to be hoped, increasing level of consumption throughout the life cycle. But this requires a pension system that promotes saving for old age during the income-earning years.

Systems that are financed through the worker's contributions are based on this theory and assume that there is a will to obtain a merit good (such as correcting short-sightedness as far as saving for old age is concerned) through the design of a mechanism whereby the State, during the active life of the pension scheme member, taps into the individual's current income in the form of a tax or social security contribution and sets aside the amount thus withdrawn to finance the system that will support that person's living expenses during old age. This contribution to the financing of the system is easier to obtain from formal workers and can be designed by resorting to different options with respect to:

i) The type of scheme, which can be based on defined contributions or defined benefits.

ii) The financing mechanism, which can be fully funded or unfunded, the latter with different premiums (for permitting actuarial adjustments and in extreme cases a simple unfunded arrangement).

iii) The form of administration, which can be public or private or a mixture of the two; and

iv) Participation, which can be mandatory or voluntary. $^{2}$

\footnotetext{
2 It is very easy to say that an independent or informal worker should participate voluntarily and that if he does not, then it is his
}

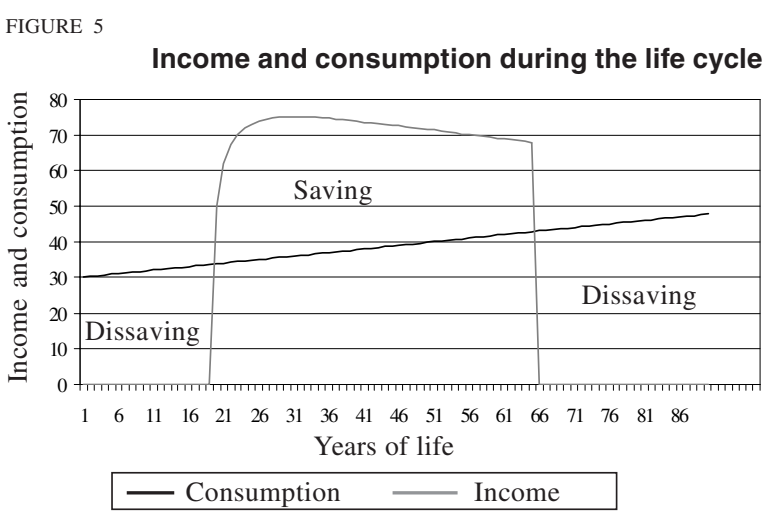

Source: Prepared by the author.

In contributory schemes financed by the unfunded method, the benefits are usually defined not by a close relation with the amounts contributed but by length of membership and a rule that determines the pension on the basis of a rate corresponding to the last or best taxable wages. In contributory fully funded systems, the contributions are usually fixed and the amount accrued determines the benefits on the basis of actuarial criteria regarding life expectancy at the time of retirement. It is interesting to note that this last criterion is being applied in unfunded systems, through the notional capitalization models implemented recently in Brazil (Carvalho Pinheiro and Paiva Vieira, 2000).

However, there are also pension systems that finance the benefits without direct contributions by beneficiaries. The State finances the payment of retirement benefits for eligible persons out of general income and consumption taxes which bring in revenue for the fiscal budget. An extreme case of this type of system is the New Zealand model, which sets a universal fixed pension: this pension, which is adjusted in accordance with the price index and bears a relationship with the average wage paid in the economy, is payable to all citizens over the age of 65 whatever their employment status during their lives and is financed entirely out of general taxes (St. John and Willmore, 2001).

problem and he should consequently be left out of the system. This argument could be used to justify the exclusion of many who are nevertheless going to need income when they retire. 


\section{V}

\section{Pension schemes: two extreme cases}

Fully funded or individual saving pension plans combine some or all of the following characteristics:

i) They are contributory: that is, financed out of workers' contributions.

ii) They are based on defined contributions: the benefit depends on the savings accrued.

iii) They are funded through individual capitalization.

iv) They are privately managed only in relation to the capitalization of savings.

v) They are obligatory only for dependent workers and not for own-account workers.

vi) The State plays a fundamental role insofar as it continues to be responsible for operating the system: it acts as regulator and supervisor of pension fund administration companies and can also play a distributional role in order to give coverage to those who do not manage to save enough and who are entitled to a minimum or welfare pension.

Universal coverage schemes, such as that of New Zealand, display some or all of the characteristics listed below:

i) They are non-contributory: they are funded through general taxes (consumption or income tax).

ii) They provide defined, universal and equal benefits for all: in New Zealand, after the age of 65 years and subject to certain residence conditions, all citizens receive a universal pension guaranteed by the State.

iii) They are based on the unfunded system and are paid for out of general taxes collected from the current generation.

iv) They are publicly administered.

v) The system is universal for all residents: it does not exclude anyone and is the same for all.

vi) The private sector fulfils a fundamental role as it is responsible for designing a voluntary, complementary savings scheme for those who wish to obtain greater benefits than those guaranteed by the State.

Different combinations of the above characteristics have permitted the design of two totally opposite schemes, such as that of New Zealand and that of Chile. The New Zealand scheme ensures that all persons have a guaranteed pension and the private sector plays a complementary role: that of promoting additional voluntary saving mechanisms. The Chilean scheme is concerned with compulsory saving, and it is the State that has a subsidiary role. As will be seen in section VIII below, there are many other possible combinations. Here we have illustrated just two extreme cases.

\section{VI}

\section{Heterogeneity of access to a pension system based on saving capacity}

A contributory system based exclusively on individual capacity to save for old age will tend to reproduce within the field of social protection the uncertainties and restrictions that limited the person in question during the active phase of his life cycle. We will thus be reproducing in the social protection system the very factors that the system should counteract.

Many families live with cash flow problems and are incapable of borrowing against future income and of saving for provident purposes, generally because their levels of current and future income are too low or erratic to sustain continuous levels of saving or because agents of loan markets perceive that these persons will have difficulties in meeting loan repayments, since they do not have suitable collateral to back up the credit. Older persons in such households reach retirement age without savings for their old age and without the income necessary for their own living expenses. 
In countries where there are mandatory retirement saving schemes, the poorer the family the lower their participation tends to be, especially in the case of women. This occurs not only because of the limited saving capacity already mentioned, but also because in the jobs that these persons have access to, it is not possible to enforce labour legislation properly and many people end up without retirement savings and thus without an income to meet their living expenses in their senior years. Figure 6 shows contributors to the private pension scheme in Chile, grouped together by poverty level, sex and age. It can be clearly seen there that if the criterion for entitlement to benefits is the fulfillment of defined contributions - that is, participation as a saver in the system- this would mean that most women as well as the active members of the poorest families, whose participation in economic activity is more insecure, so that they are less likely to keep up their status as members of the system, would be left without benefits (that is to say, without coverage). Furthermore, many of those who, although they appear on the list of contributors at a given time, do not participate regularly

FIGURE 6

Chile: contributors by poverty level, age and gender

Chile 1998: Total population

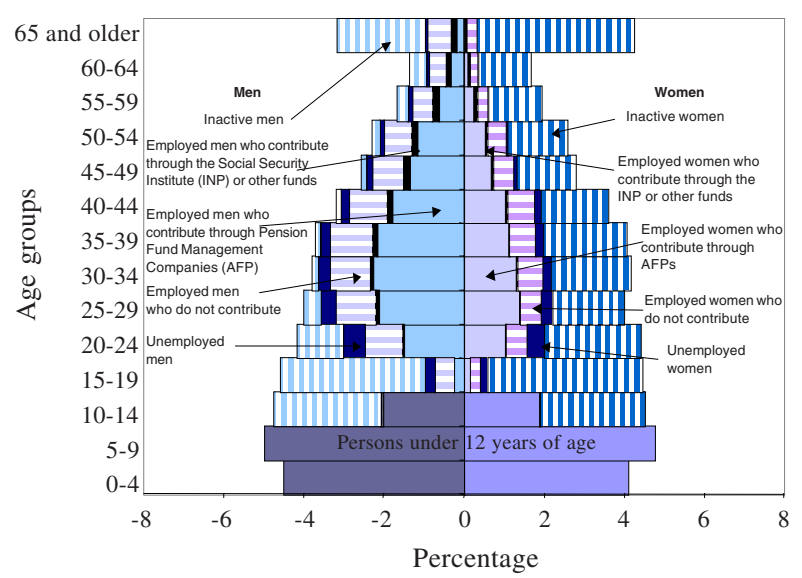

Non-indigent poor (16.0\%)

(Percentage of persons)

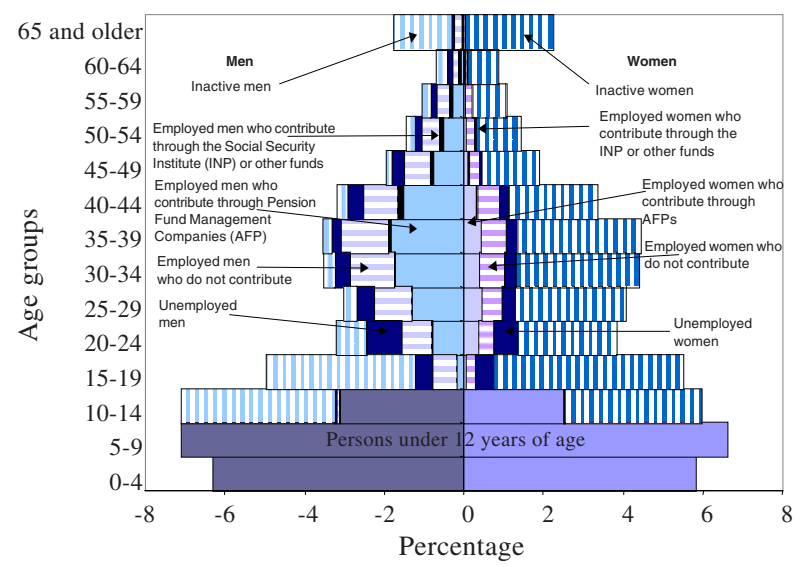

Indigent persons $(5.6 \%)$

(Percentage of persons)

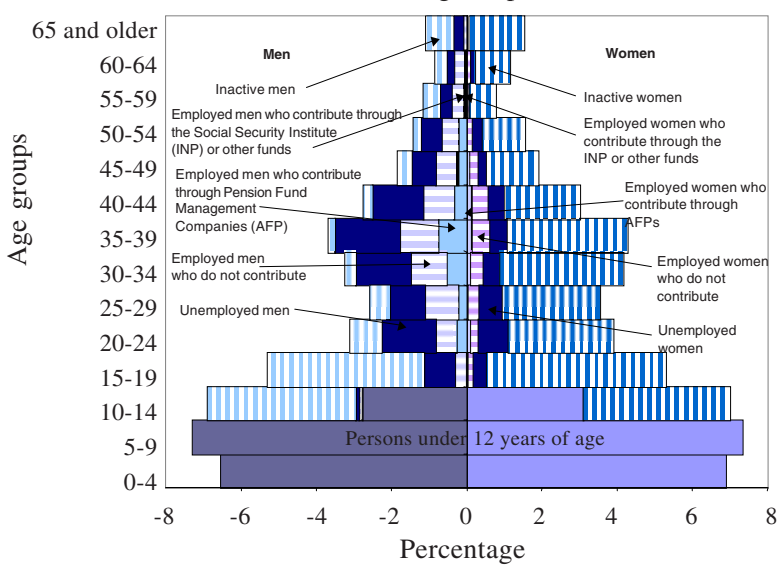

Non-poor $(78.4 \%)$

(Percentage of persons)

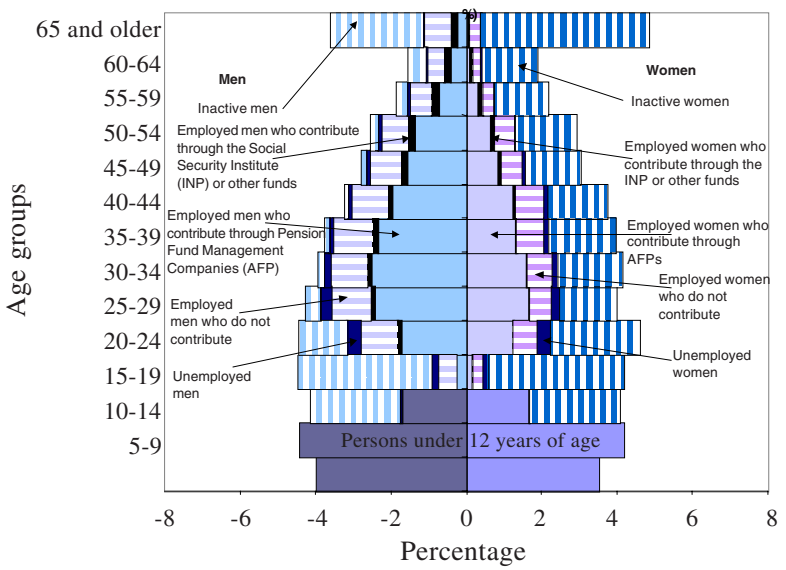

Source: Prepared by the author on the basis of the 1998 National Socio-economic Survey (CASEN) (Ministry of Planning and Cooperation (MIDEPLAN), 1998). 
and therefore have a low density of contribution (saving frequency) will also be left without coverage. The same would apply to those who may have contributed regularly but on the basis of very low incomes.

Because of the nature of their financing formula, systems that are designed on the basis of families' saving capacity will limit access to benefits as follows:

i) Uninsured without capacity to save. The most extreme case is that of poor families who have to live exclusively on a subsistence income. They have no access to loan markets and therefore face permanent cash flow problems, so that they adjust their living expenses to a subsistence level that matches their current income. Their situation does not change substantially with the cycle, except that there are more and more families joining their ranks. They have no capacity to save and should be the subject of welfare policies as regards saving for old age.

ii) Highly vulnerable uninsured persons. Next on an ascending scale are those families which have been able to escape from the situation of living at subsistence levels and can earmark part of their current income for savings, but because of their vulnerability to the economic cycle and unemployment, they must adjust their expenditure to subsistence levels, interrupting their saving efforts time and again, so that they may never be able to save on a continuous basis at a level that guarantees them a decent pension for their old age. These persons will also be candidates for welfare pensions.

iii) Partially insured owing to their vulnerability. Next on the scale are those families that are still vulnerable to the situation of the economic cycle and must adjust their expenses to conditions of uncertainty and liquidity restrictions, albeit to a lesser degree, and that manage to save satisfactorily in terms of continuity but not in terms of the amount needed to afford them a decent pension. For this reason they too will be candidates for support through minimum pensions.

iv) Fully insured because of their saving capacity. Lastly, there is a higher income, more highly skilled group which is less vulnerable to the economic cycle. Part of their income can be set aside as savings on a continuous basis and in greater amounts that will be sufficient to self-finance their living expenses (old-age pension) at a satisfactory level.

\section{VII}

\section{Contingent liabilities and system design options}

The options for designing systems are not neutral and force the representatives of society to take a decision on the type of objectives they are pursuing. The design has enormous repercussions on the way the system's social and economic functions are harmonized.

Non-contributory defined benefit models, administered by distribution (unfunded systems), which draw on general State-administered tax revenue and are obligatory for all residents of the country can be the basis for a universal, equal and solidary system. Their success will depend on their capacity to ensure a satisfactory income for all citizens of retirement age, not only those that contributed to economic activity, thereby attenuating income inequality among retirees and protecting the latter against the uncertainty of sudden social and economic changes. While the accent is on the social function, in ensuring universal access to benefits, such systems are only acceptable and fiscally responsible if the benefits can be funded sustainably over time.
The model applied in New Zealand places emphasis on equity and universality, guaranteeing access to income for the retirement years on the strength of a person's having been a citizen for more than 10 years and having contributed in some way to society, without distinction. However, the financing of this model generates a heavy fiscal burden and does not contribute to the development of capital markets. When financing comes from consumption taxes it may be regressive, but the fact that it is used for equal pensions which are taxable makes it possible in the end to recover part of the cost through the taxation of higher income earners. Since the system is noncontributory, it has the advantage of minimizing distortions that prevent the hiring of labour. Pensions are adjusted in line with inflation but cannot be below $65 \%$ of the average wage. The cost of this benefit amounted to 5\% of GDP in 2000 and is expected to be rather less than $11 \%$ in 2050 (St. John and Willmore, 2001). 
Preliminary illustrative calculations for this option for some Latin American countries are given in table 1. They show that the model is sensitive not only to the proportion of persons over 65 years of age but also, and in particular, to the amount of the benefit, which in this case is estimated as being equivalent to the minimum wage and whose "generosity" can be seen in relation to per capita GDP. The economic cost to countries of sustaining this option (measured as a percentage of GDP) depends not only on the proportion of the population over 65 years of age but also, and especially, on the relative generosity of the benefit, measured in terms of the relationship between the minimum wage and per capita GDP. An extreme example is that of Paraguay, where population ageing is incipient but the minimum wage is high (table 1 and figure 7).

At the other extreme is a system that rewards individual effort to finance a pension on the basis of savings accrued during one's active life. This does not place the accent on the social function, since it does not guarantee universal coverage and the benefit differs between individuals, with large numbers running the risk of being left without insurance. It is based on defined contributions with individual capitalization. In order to contribute to the development of the capital market, there must be an initial phase (until a whole generation joins the system) with high transition costs, which imply significant fiscal responsibilities. The pension provided under this system is based on savings. If these are low -lower than the established guaranteesit can have the effect of shifting many towards the State-
FIGURE 7

Relationship between cost and "generosity" of pensions

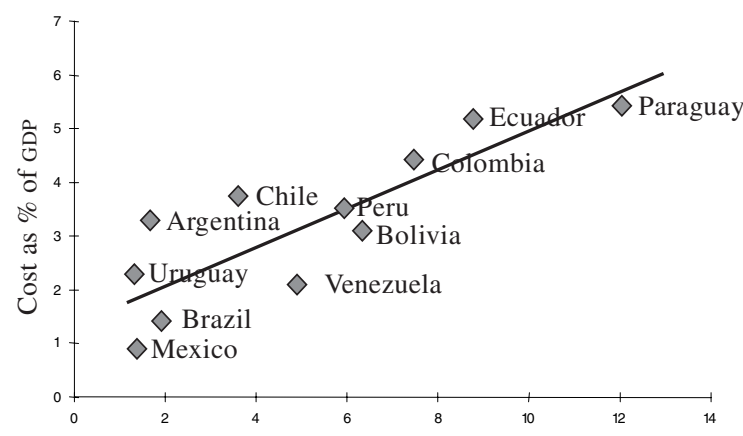

"Generosity" = Minimum pension as \% of per capita GDP

Source: Table 1.

subsidized benefits, thus affecting the solvency of the fiscal accounts.

The Chilean model is similar to this alternative, since it distinguishes between those who have the capacity to save and those who do not and, from among the former, it selects those who can be made to contribute by the State and in respect of whom suitable controls can be exercised. Its creation, in replacement of a former unfunded system, generated a heavy fiscal burden to cover the transition costs involved in the payment of current pensions and the recognition of contributions made to the old system by those who have transferred to the new. In addition, it has led to costs in

TABLE 1

Latin America: The challenge of financing a universal pension scheme (For 2001 data)

\begin{tabular}{lccc}
\hline Country & $\begin{array}{c}\text { Amount of } \\
\text { pension } \\
\text { (dollars) }\end{array}$ & $\begin{array}{c}\text { Percentage of } \\
\text { population } \\
\text { over } 65\end{array}$ & $\begin{array}{c}\text { Pension as a } \\
\text { percentage of } \\
\text { per capita GDP }\end{array}$ \\
\hline Argentina & 200.1 & 9.7 & 2.8 \\
percentage \\
of GDP
\end{tabular}

Source: Prepared by the author on the basis of official ECLAC data. 
respect of the guarantees of minimum and welfare pensions for the civil population and the pensions of retired members of the Armed Forces.

The annual cost of the transition, the guaranteed minimum pensions and the pensions of the Armed Forces has been estimated at 5.5\% of GDP for the first 21 years (figure 8). In the long run, the cost should coincide with the amount corresponding to the guarantees. This will depend on the number of persons who are underinsured or uninsured owing to their low levels of savings and the increase in life expectancy and the pensions of the Armed Forces, for as long as the latter continue with their present system of pensions. The pensions of members who are insured are uncertain, since they depend on the density of their contributions, the profitability that they obtain during their period of contribution, and their life expectancy at retirement. Furthermore, it is necessary to deduct the fees charged by pension fund administration companies during the period of accumulation and the insurance premium for obtaining a life annuity (there are also other options) for the retirement years. The guaranteed benefits in the form of welfare pensions and minimum pensions are currently well below the minimum wage (figure 8 ).
FIGURE 8

Chile: Total social security deficit

(As a percentage of GDP)

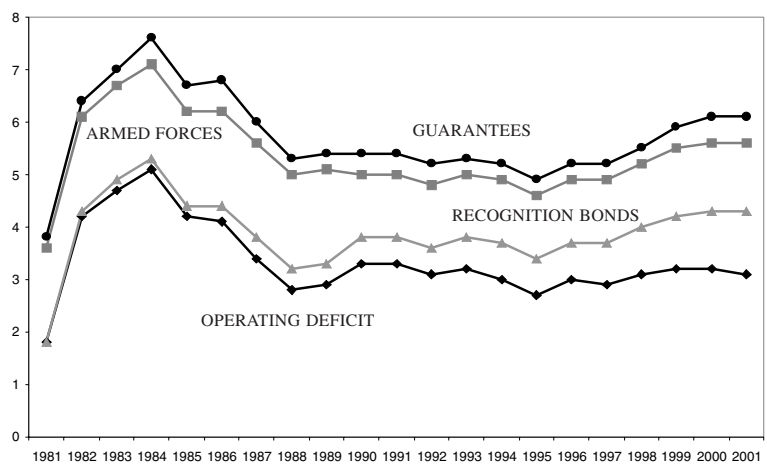

Source: Arenas de Mesa (1999).

The impact on development of the capital market is enhanced if the State finances this cost through higher taxes, lower expenditure in other sectors and income from privatization. Otherwise, the State becomes the principal factor of absorption of the pension fund resources, minimizing their impact on the development of the capital market.

\section{VIII}

\section{Current status of capitalization schemes in Latin America}

In the structural reforms of contributory models, capitalization or fully funded plans have not always replaced the former unfunded systems. There are four types of models: individually funded plans that take the place of an unfunded scheme (Chile, 1981; Bolivia, 1997; Mexico, 1997, and El Salvador, 1998); mixed plans, where an unfunded system is supplemented with a capitalization system (Argentina, 1994; Uruguay, 1996, and Costa Rica, 2001; parallel schemes, where there is competition between an unfunded system and a funded system (Colombia, 1994 and Peru, 1993), and notional models that apply defined contribution schemes to unfunded models (Brazil, 2000). ${ }^{3}$

${ }^{3}$ See Mesa-Lago (1999) and Carvalho Pinheiro and Paiva Vieira (2000).
There are three fundamental issues that reveal the limitations imposed by the labour market on systems involving individual capitalization accounts: coverage, capital market development, and administration fees. ${ }^{4}$

\section{Coverage}

As may be seen from figure 9, individual capitalization systems continue to exclude a high percentage of the economically active population and therefore place the burden of expanding coverage on other sources of financing. In terms of numbers of members, a report

\footnotetext{
${ }^{4}$ The differing characteristics of the countries in general and the individual systems in particular, as well as the different lengths of time they have been in existence, mean that caution should be exercised in making any comparison.
} 
FIGURE 9

Coverage of individual capitalization schemes, December 2001

(Contributors as a percentage of EAP)

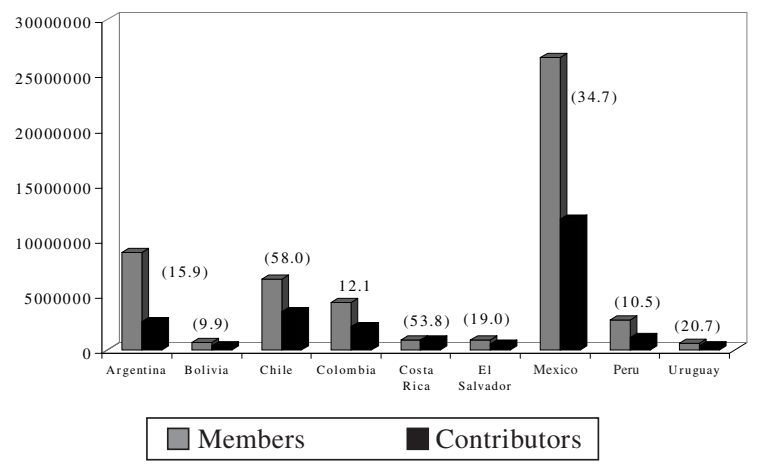

Source: AIOS, 2001.

by the International Association of Pension Fund Supervisory Bodies (AIOS) based on a simple average of nine countries shows a high rate of coverage: $63.7 \%$ of the economically active population in December 2001. However, only $27.7 \%$ of members effectively contribute to the system: that is, approximately six out of every 10 members do not contribute regularly to the system. This difference between members and contributors gives grounds for speculating that the density with which members save in the system is very low, so that they will not be able to accumulate sufficient funds to finance their own pensions and will therefore have to receive subsidies from the State in their capacity as under- or un-insured persons who are entitled to basic (minimum) and welfare pensions.

Figures from the Ministry of Labour of Chile indicate that only $4 \%$ of independent workers contribute (although in their case they are not obliged to contribute) and that more than half of women members contribute less than $30 \%$ of the time that they work, compared with $40 \%$ in the case of men. Another study for Chile indicates that most members contribute just enough to receive the minimum State-guaranteed pension -which today is slightly over US\$100investing their resources instead in other things, such as their children's education or a house of their own (El Mercurio, 2002).

\section{Capital market development and profitability}

Whether individual capitalization plans will contribute effectively to the generation of employment through the development of capital markets and will result in more profitable pension solutions depends on many factors. Firstly, there must be a proper context for longterm investment decisions, characterized by inflation that has been reined in and kept at low levels (and/or an indexed financial system); positive but moderate real interest rates, and a realistic exchange rate. The purpose is to create long-term planning time frames which can allow for the efficient allocation of capital resources under internationally competitive conditions.

Institutional measures are also needed in the financial sphere to generate sound competition for longterm investment resources. These measures include improving public sector solvency; promoting prudential and organizational regulation of the banking system with a view to avoiding crises, and developing securities markets so as to facilitate transparency in risk analysis and thus make it possible to take informed investment decisions and protect small investors.

Both the lack of such measures and the enforcement of strict regulations on pension funds have so far prevented full diversification of these funds' investment portfolios, which are concentrated to a large extent in government debt securities. Of the total of the funds administered by these systems, $59 \%$ is invested in government debt securities, $18 \%$ in financial institutions and only $8 \%$ in stocks (figure 10).

The direct impact of the funds on real investment is uncertain. With the exception of investment in mortgage instruments, the counterpart of which is the construction of housing to be acquired by the borrowing

\section{FIGURE 10 \\ Latin America (eight countries): Composition of administered funds}



Source: AIOS, 2001. 
public, there are no instruments which increase the country's wealth rather than purchasing already existing assets or financing current expenditure.

Gross annual returns ${ }^{5}$ on the funds since their creation have been high in all instances, bearing a relationship with the rise in the value of government debt instruments, but in the last few years sharp reductions have been observed. While the simple average of real historic rates of return ${ }^{6}$ is $10.4 \%$, the figure for January to December 2001 was only 5.9\% (figure 11). The returns for each individual will naturally depend on the year of entry into and exit from the individual capitalization scheme and the fund's profitability during this period, after deduction of administration fees.

\section{Administration fees}

A very important point to note in these circumstances is that those who contribute to a fully funded plan must pay a series of extra charges over and above their contribution to their individual account; these include disability insurance, life insurance and a net commission to cover the administration expenses of the fund in question. According to the AIOS report, in the region, as a percentage of their taxable salary, Latin American workers pay average total charges of 3\%, of which $1.25 \%$ is for disability insurance and life insurance and $1.75 \%$ for the administration fee. Pension fund administration companies must capitalize an average of $9 \%$ of their members' taxable salary. The simple average among countries for the cost of these fees as a percentage of workers' total contributions is $25 \%$, and the average as a percentage of the capitalizable contribution is $33 \%$, although there are substantial differences between countries. ${ }^{7}$

Bearing in mind the coverage characteristics and the projections that indicate that many workers will not manage to save enough to benefit from the fully funded system, it may be wondered whether the payment of fees to the pension fund management companies is not a contribution that the system loses

\footnotetext{
${ }^{5}$ Without taking into account the effect of fees charged by the administrators.

${ }^{6}$ That is, deflating nominal profitability for the variation in consumer prices.

${ }^{7}$ In view of the different concepts and experiences, caution should be exercised when making such comparisons.
}

FIGURE 11

\section{Latin America (eight countries): Real gross returns on pension funds}



Source: AIOS, 2001.

as part of the financing and administration of the Stateguaranteed benefits. ${ }^{8}$

The question of fees has been extensively discussed, even with regard to workers who are fully insured under the fully funded plan. In such cases, it is argued that the return on the worker's contribution differs from that of the worker's account because it does not take into account the cost of the fees, which is borne by the worker. This is illustrated in the case of Chile in table 2. Although the return on the contribution (the extent to which the share in the total amount of the funds administered by a pension fund management company appreciates) between 1981 and 1999 was $11.2 \%$, the return on different individual accounts varied significantly depending on the level of income and the period of contribution of each individual. It may be concluded that members assume the cost of the fees and the system's financial risk in a regressive manner. If a member has had to participate in the system when the fees were high and returns on investment low, he would thereby have a significantly lower pension than another member who has participated at times when rates of return have been high and fees low. The situation is much worse for members with low incomes.

\footnotetext{
${ }^{8}$ This argument loses force when the contribution and its capitalization are used to finance part of the guarantees of workers who are underinsured and the fee is considered as a payment for the services of capitalizing the worker's balance during this period.
} 
TABLE 2

Chile: Annual rate of return on the individual account and the contribution

(Per cent)

\begin{tabular}{lccccc}
\hline Chilean pesos & 80500 & 147954 & 221930 & 443861 & 887722 \\
\hline May 1998-April 1999 & 3.79 & 3.91 & 3.95 & 4.00 & 4.02 \\
May 1996-April 1999 & 3.21 & 3.28 & 3.31 & 5.34 & 3.35 \\
May 1993-April 1999 & 5.04 & 5.10 & 5.13 & 5.15 & 7.62 \\
May 1987-April 1999 & 6.97 & 7.09 & 7.14 & 7.19 & 7.05 \\
May 1981-April 1999 & 7.24 & 7.41 & 7.47 & 7.54 & 7.57 \\
\hline
\end{tabular}

Source: Office of the Superintendent of Pension Fund Management Companies (1999).

\section{IX}

\section{Conclusions}

The fundamental social function of a pension system must be to achieve universal coverage, providing decent old age and disability pensions for income-earners and survivors' benefits for dependents after the death of the contributor, as well as coverage for non-income earners. Fundamentally, the clash with the system's economic functions lies in the fiscal responsibilities that the State may have to assume as a consequence of the challenge that the design of the system may impose on it: providing coverage for different persons, whatever their employment situation.

A contributory unfunded scheme with a graduated average premium and fixed benefits runs the risk of turning into a simple unfunded system as a result of erosion of its reserves, which may eventually call for a high component of public financing. However, its replacement by a system funded by individual savings accounts does not completely obviate this tendency, since the labour market limits the capacity of many of its members to achieve the required contribution density, so that they will eventually become eligible for State guarantees whose costs must be added to those of the transition.

Hence fiscal responsibilities do not disappear and the State must assume several obligations, including:

- Payment of pensions currently due to retirees under the old system.

- Payment of entitlements already acquired by current contributors through their contributions to the old system, when these contributors transfer to the new system.

- Payment of State-guaranteed pensions, whether they be minimum or welfare pensions or those due to the Armed Forces or to other groups entitled to them by law.

The net reserves of the old system are available for financing these commitments.

It is hard to estimate the cost of these responsibilities, partly because not all countries have opted for total substitution of one system by another, owing precisely to the very high fiscal commitments that this would entail. Generally speaking, however, countries have had to confront this dilemma when designing their pension systems, and in the case of reform, when replacing one system by another, have had to opt for one of the following alternatives:

- Not assuming the responsibilities in question, which has a high political cost and is prejudicial to retirees and workers who contributed to the old system.

- Financing them with new debt, which has a cost for future generations and affects the public sector demand for financial resources.

- Financing them with fiscal surpluses, which has significant fiscal implications and affects current generations.

Faced with these dilemmas, Argentina, Uruguay, Colombia, Peru and Costa Rica opted for two-pillar systems - unfunded and fully funded-and adjusted the unfunded system to make it more viable financially, either by raising the retirement age, increasing contributions and/or reducing pensions. None of these cases makes due provision for the fact that once a capitalization fund reaches maturity:

- Many persons will nevertheless qualify to receive minimum and/or welfare pensions, which will 
oblige the authorities to make major adjustments in public finances or reforms of the reforms.

- Those reaching retirement age with sufficient savings will have to adjust their benefits to rising life expectancy, and at the same time will be forced to take decisions relating to a higher retirement age, a reduction in benefits or the payment of additional voluntary contributions. In view of the heterogeneity of Latin American societies, which is reflected particularly strongly in the labour market, the conclusion is that further reforms to the pension systems will be necessary. Contributory unfunded solidary financing mechanisms must be strengthened to give coverage to those who, through their particular employment situation, would be left uninsured or underinsured under individually funded systems.

(Original: Spanish)

\section{Bibliography}

AIOS (Asociación Internacional de Organismos de Supervisión de Fondos de Pensiones) (2001): Boletín estadístico, No. 6, Buenos Aires, December.

Arenas de Mesa, A. (1999): Efectos fiscales del sistema de pensiones en Chile: Proyección del déficit previsional, 1999-2037, paper presented at the seminar "Responsabilidades fiscales de los sistemas de pensiones", Santiago, Chile, Ministry of Finance /Economic Commission for Latin America and the Caribbean (ECLAC), 2-3 September.

(2000): El sistema de pensiones en Chile: resultados y desafios pendientes, "Seminarios y conferencias" series, No. 2, LC/L.1399-P, Santiago, Chile, ECLAC.

Barr, N. (2000): Reforming Pensions: Myths, Truths, and Policy Choices, IMF working paper No. 139, Washington, D.C., International Monetary Fund (IMF).

Carvalho Pinheiro, V. and S. Paiva Vieira (2000): Reforma previsional en Brasil: la nueva regla para el cálculo de los beneficios, "Financiamiento del desarrollo" series, No. 97, LC/L.1386-P, Santiago, Chile, EClaC.

ECLAC (Economic Commission for Latin America and the Caribbean) (1996): Strengthening Development: The Interplay of Macro- and Microeconomics, LC/G.1898, Santiago, Chile.

ECLAC/CELADE (Latin American and Caribbean Demographic Centre) (1999): Latin America: economically active population, 19802025, Demographic Bulletin, vol. 32, No. 64, LC/G.2059, Santiago, Chile.

(2002): Latin America and the Caribbean: population estimates and projections, 1950-2050, Demographic Bulletin, vol. 35, No. 69, LC/G.2152-P, Santiago, Chile.

El Mercurio (2002): Santiago, Chile, 8 August, p. B.6.

ILO (International Labour Organisation) (2001a): Seguridad social: temas, retos y perspectivas, Geneva. (2001b): 2001 Labour Overview, Latin America and the Caribbean, Lima.

Mesa-Lago, C. (1999): La reforma estructural de pensiones en América Latina: tipología, comprobación de presupuestos y enseñanzas, in A. Bonilla and A. Conte-Grand (comps.), Pensiones en América Latina. Dos décadas de reforma, Lima, International Labour Organisation (ILO).

Ministry of Planning and Cooperation (MIDEPLAN) (1998): Encuesta de caracterización socioeconómica nacional, CASEN 1998, Santiago, Chile.

Ocampo, J. A. (coord.) (2001): Crecer con estabilidad. El financiamiento del desarrollo en el nuevo contexto internacional, Santafé de Bogotá, ECLAC/Alfaomega.

Office of the Superintendent of Pension Fund Administration Companies (1999): Boletín Estadístico, No. 149, Santiago, Chile.

Orszag, P. and J. Stiglitz (1999): Rethinking pension reform: Ten myths about social security systems, paper presented at the conference "New Ideas about Old Age Security", Washington, D.C., World Bank, 14-15 September.

St. John, S. and L. Willmore (2001): Two legs are better than three: New Zealand as a model for old age pensions, World Development, vol. 29, No. 8, Oxford, U.K., Pergamon Press, Ltd.

Titelman, D. and A. Uthoff (1997): La relación entre el ahorro externo y el ahorro nacional en contextos de liberalización financiera, in R. Ffrench-Davis and H. Reisen (comps.), Flujos de capital e inversión productiva: lecciones para América Latina, Santiago, Chile, McGraw-Hill.

World Bank (2001): World Development Indicators 2001, Washington, D.C. 